\title{
A life well lived: Joanna Jones (Kain) 1930-2017
}

\author{
Alecia Bellgrove ${ }^{1}$ \\ Received: 26 September 2017 / Revised and accepted: 1 October 2017 / Published online: 19 October 2017 \\ (C) Springer Science+Business Media B.V. 2017
}

Passionate, dedicated, scrupulous, engaged, committed, analytical, independent, witty, argumentative, shy and organised; Jo was an amazing role model of a practising scientist and a mentor for phycologists of several generations.

Born in 1930 in Christchurch, New Zealand, to an English mother and a Kiwi father, Jo moved to London at the age of 2 and spent most of her life in the UK. Her father named her Dorothy Kain, but her mother never liked this name and called her Anne. Being incredibly sensible and decisive, she decided to end the debate at the age of 10 and change her name to Joanna, after her favourite doll.

Jo's early education was disrupted with moves to 10 different schools, but when she eventually made it to University College London (UCL) in 1949, she became hooked on science and in particular, marine algae. She recently recalled that she was introduced to the algae by G E (Tony) Fogg, who started his first lecture with a Greek or Latin quotation which meant 'nothing is as foul as an alga' and then effectively proved this to be wrong. UCL did not run a marine field course at that time but Bedford College did and she was allowed to join them when they went to the Isle of Man. This left Jo in no doubt that the algae were the most interesting of the plants. For her undergraduate research project, Jo studied the patterns of intertidal zonation around the Isle of Wight, where the tidal ranges differed from the open coast.

Whilst Jo was principally interested in the ecology of macroalgae, she was offered a $\mathrm{PhD}$ at UCL under the supervision of Tony Fogg, funded by the Institute of Seaweed

Alecia Bellgrove

alecia.bellgrove@deakin.edu.au

1 School of Life and Environmental Sciences, Centre for Integrative Ecology, Deakin University, Warrnambool Campus, P.O. Box 423, Warrnambool, Victoria 3280, Australia
Research, to investigate the growth of marine phytoplankton, so she took it and graduated in 1957. In 1956, she was appointed 'Algologist' at Port Erin Marine Laboratory, University of Liverpool. It was at Port Erin that Jo first met Norman Jones, whom she later married at the age of 32 and had two children, Martin and Bidda. She remained at Port Erin Marine Laboratory for 44 years.

Jo enjoyed the huge freedom and privilege of not having any undergraduate teaching obligations for the first 16 years of her academic career and was able to devote herself solely to research (half her luck!). From 1972, she was involved in teaching both a vacation intensive course and the honours course, in which the student numbers increased from 9 to over 30 per year during her time, increasing her access to potential PhD students. Jo successfully supervised $18 \mathrm{PhD}$ students to completion, many of whom have gone on to become important phycologists in their own right, including Emeritus Prof Di Walker (University of Western Australia) and Prof Taejun Han (Incheon National University, Korea).

Jo's love of the ocean and adventurous spirit (Fig. 1) saw her an early adopter of the mask, fins and snorkel (with a pingpong ball valve) to snorkel in the early 1950s and allow her to discover a whole new world. Then, when the aqualung became available in the late $1950 \mathrm{~s}$, Jo, of course, jumped at the opportunity to give it a try. In post-WWII UK, when women enjoyed freedoms not previously known, Jo was one of several notable female phycologists and marine biologists. Jo was an early adopter of scuba diving and a pioneer of subtidal research. She was one of the first women to qualify as a first-class diver, which initially involved diving solo on a line until she later found a buddy in her husband Norman (pictured with Jo in scuba gear in Fig. 1) and then subsequently the Chief Diver at Port Erin Marine Laboratory, Mike Bates, kept her in sight. Together they trained many students to dive. Jo was so into diving and research that she even had a special 

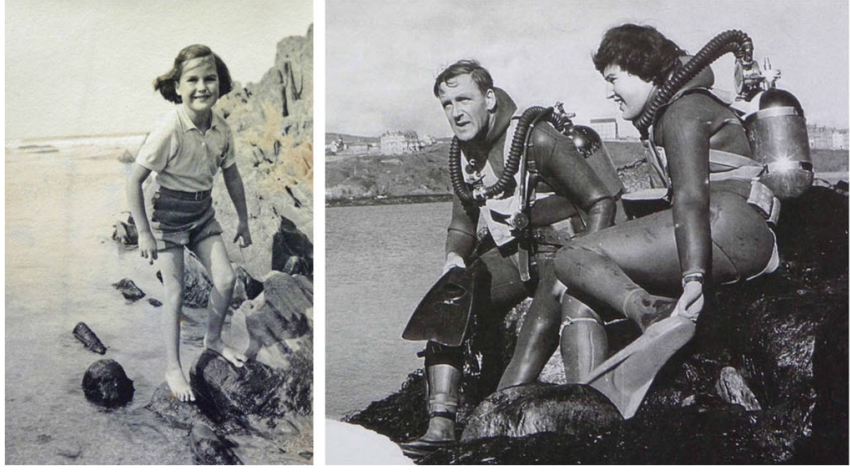

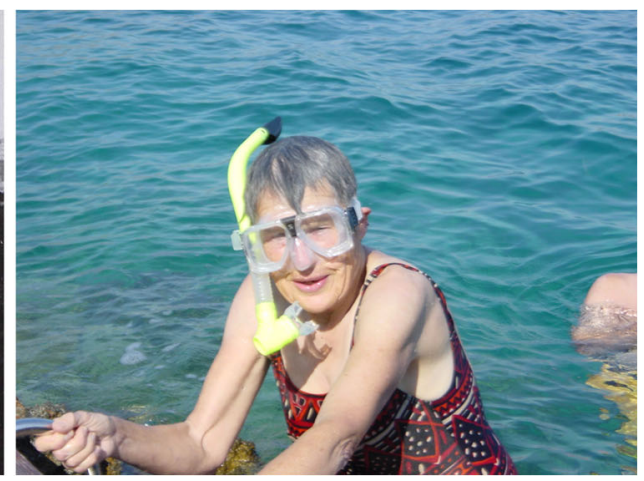

Norman Jones at Port Erin, UK, early 1960s. Right If you can, do! Still snorkelling on the Greek island of Lefkada at age 77

her research focus to the reds for the next two decades, where she was primarily interested in understanding the phenology of a few key species. For example, Jo was fascinated to discover that the critical length of the photoperiod that controlled the phenology of Delesseria differed with the life-history phase. During this latter period, Jo also collaborated on a number of research projects that explored the commercial cultivation and economic potential of a suite of red, green and brown macroalgae.

By 1991, at the age of 61, Jo had officially retired; but of course, that did not stop her from continuing to follow her curious mind into various research projects, and she was supported to do so at Port Erin Marine Laboratory. Following Norman's death in 1997, Jo migrated to Canberra, Australia, in 2000 , to be closer to her daughter and family. She was now 70 and had recently given up diving. So the ever practical Jo, arranged herself a Visiting Fellowship at the Australian National University, and chose an intertidal project monitoring both a brown crust (which turned out to be Colpomenia

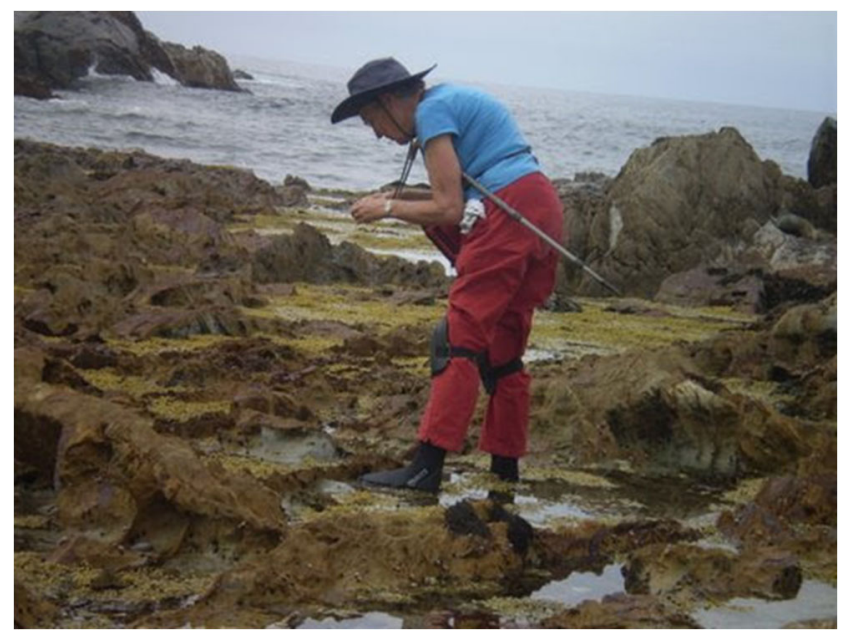

Fig. 3 Jo at Kianga Reef, NSW, Australia, conducting research on Hormosira banksii. Nearly 80 by this stage and armed with a walking stick for stability on the reef, Jo was not about to let her age and declining mobility keep her from finishing her research project. This work contributed to Jo's final publication in 2015 (\#80 in her publication list) 
bullosa crust masquerading as Ralfsia verrucosa) and Hormosira banksii in some high pools on the south coast of New South Wales for 12 years (Fig. 3).

Jo published 61 papers during her working life and then a further 19 following her official retirement in 1991. Her last paper was published in 2015 and presented at the Australasian Society for Phycology and Aquatic Botany conference in Hobart. She already had cancer at this stage.

Jo was a passionate and active phycologist and gave generously to her discipline. She joined the British Phycological Society as a student, attended a total of 44 annual meetings over 47 years, and was Honorary Secretary for 7 years from 1977, Vice President, then President 1985-88 and Honorary Fellow from 2000. Jo had also become a member of the Australasian Society for Phycology and Aquatic Botany (ASPAB) in 1981, only a year after it was founded, and, after migrating to Canberra, attended all meetings until 2015. She became Treasurer of ASPAB when she arrived in Australia and diligently served in this role for 15 years until retiring due to illness in 2015. It was with great disappointment that Jo was unable to travel to attend the 2016 meeting in Warrnambool. Jo also actively participated in international phycological meetings, including an unbroken run of 14 International Seaweed Symposia. ${ }^{1}$ In the 1980 s and 90 s, she was the UK representative on the European Commission Management Committee (COST 48 and 49) encouraging cooperation in the production of marine algal biomass, and organised three workshops. Jo was a staunch supporter of student participation in conferences and workshops, and argued vocally for ASPAB to generously dish out student travel grants each year. This grant will now be renamed in her honour.

Jo was extraordinarily organised and practical, but once she had considered the options and then decided on the way to do something, one would be hard-pressed to get her to change her mind. She could usually be found with her little waist pack on, complete with all manner of handy items that one might at some stage be looking for. [When recently reading Enid Blyton's Famous Five to my son, I amused myself thinking that Jo would have made a good addition to the little adventurous team, with a pocket knife, box of matches, piece of string, sewing kit and safety pins always on hand.] I am sure that it was this no-nonsense approach to life that enabled Jo to have such a long and successful scientific career. When I asked her recently how she'd ventured into science and scuba-based research at a time when there were many more obstacles than open doors for women, she matter-of-factly told me (almost as if it was a silly question) that she had supportive parents and that she just never thought that she could not do what the boys and men were doing! In the words of Jo's

\footnotetext{
${ }^{1}$ Editor's note: Jo often reviewed papers for the Journal of Applied Phycology and her reviews were always insightful, detailed but clear, with useful guidance on how the paper could be improved.
}

daughter: 'Growing up with her as a role model, she taught me that being female is never an excuse to not try something it's merely a matter of how determined you are to succeed.' Jo similarly demonstrated that age is also no impediment!

Jo was diagnosed with terminal oesophageal cancer in 2015. She died peacefully in her home in Canberra on Friday, 21 July 2017 at the age of 87, with her reading glasses on and her iPad by her side. Jo decided it was time to go, so she did. She'd had a good life and contributed much to science.

She will be remembered.

She will be missed.

Acknowledgements Special thanks to Bidda and Martin Jones for assistance in preparing this article and for the photos from their family collection. Thanks are also to Di Walker for some words to encapsulate Jo, and Margaret Clayton for reviewing the manuscript. A recent biography prepared by Jo was used in preparing this article.

\section{Chronological Publication List of Joanna Jones (Kain)}

Kain JM (1958) Observations on the littoral algae of the Isle of Wight. J Mar Biol Ass UK 37:769-780

Kain JM, Fogg GE (1958) Studies on the growth of marine phytoplankton. I. Asterionella japonica Gran. J Mar Biol Ass UK 37:397-413

Kain JM, Fogg GE (1958) Studies on the growth of marine phytoplankton. II. Isochrysis galbana Parke. J Mar Biol Ass UK 37:781-788

Kain JM, Fogg GE (1960) Studies on the growth of marine phytoplankton. III. Prorocentrum micans Ehrenberg. J Mar Biol Ass UK 39: $33-50$

Kain JM (1960) Direct observations on some Manx sublittoral algae. J Mar Biol Ass UK 39:609-630

Kain JM (1961) Algal species lists: some sublittoral records. Br Phycol Bull 2:80-86

Kain JM (1962) Aspects of the biology of Laminaria hyperborea. I. Vertical distribution. J Mar Biol Ass UK 42:377-385

Kain JM (1963) Aspects of the biology of Laminaria hyperborea. II. Age, weight and length. J Mar Biol Ass UK 43:129-151

Kain JM (1964) A study on the ecology of Laminaria hyperborea (Gunn.) Fosl. In: Davy de Ville, A., Feldmann J (eds) Proceedings of the fourth International Seaweed Symposium : Biarritz, September 1961, Pergamon, Oxford pp 207-214.

Kain JM (1964) Aspects of the biology of Laminaria hyperborea. III. Survival and growth of gametophytes. J Mar Biol Ass UK 44:415 433

Jones NS, Kain JM (1964) The numbers of O-Group plaice in Port Erin Bay in August 1963 observed by diving. Rep Mar Biol Stn Port Erin 76:19-25

Kain JM (1965) Aspects of the biology of Laminaria hyperborea. IV. Growth of early sporophytes. J Mar Biol Ass UK 45:129-143

Jones NS, Kain JM, Stride AH (1965) The movement of sand waves on Warts Bank, Isle of Man. Mar Geol 3:329-336

Kain JM (1966) The role of light in the ecology of Laminaria hyperborea. In: Bainbridge R, Evans GC, Rackham O (eds) Light as an Ecological Factor. Blackwell, Oxford, pp 319-334

Jones NS, Kain JM (1967) Subtidal algal colonization following the removal of Echinus. Helgol Wiss Meeresunters 15:460-466 
Kain JM (1967) Populations of Laminaria hyperborea at various latitudes. Helgol Wiss Meeresunters 15:489-499

Kain JM (1969) The biology of Laminaria hyperborea. V. Comparison with early stages of competitors. J Mar Biol Ass UK 49:455-473

Kain JM, Svendsen P (1969) A note on the behaviour of Patina pellucida in Britain and Norway. Sarsia 38:25-30

Kain JM (1971) Continuous recording of underwater light in relation to Laminaria distribution. In: Crisp DJ (ed) Proceedings of the IVth European Marine Biology Symposium. University Press, Cambridge, pp 335-346

Kain JM (1971) Measurement of underwater light. In: Holme NA, McIntyre AD (eds) IPB Handbook No.16, Methods for the Study of Marine Benthos. Blackwell, Oxford \& Edinburgh pp 53-58

Kain JM (1971) The biology of Laminaria hyperborea.VI. Some Norwegian populations. J Mar Biol Ass UK 51:387-408

Kain JM (1971) Synopsis of biological data on Laminaria hyperborea. FAO Fish Synops 87:74

Hopkin R, Kain JM (1971) A preliminary report on the effect of marine pollutants on Laminaria hyperborea. Mar Pollut Bull 2:75-77

Svendsen P, Kain JM (1971) The taxonomic status, distribution and morphology of Laminaria cucullata sensu Jorde and Klavestad. Sarsia 46:1-22

Kain JM (1975) The biology of Laminaria hyperborea.VII. Reproduction of the sporophyte. J Mar Biol Ass UK 55:567-582

Kain JM (1975) Algal recolonization of some cleared subtidal areas. J Ecol 63:739-765

Kain JM (1976) The biology of Laminaria hyperborea.VIII. Growth on cleared areas. J Mar Biol Ass UK 56:267-290

Kain JM (1976) The biology of Laminaria hyperborea.IX. Growth pattern of fronds. J Mar Biol Ass UK 56:603-628

Kain JM (1976) New and interesting algae from the Shetland Isles II. Hollow and solid stiped Laminaria (Simplices). Br Phycol J 11:1-11

Kain JM, Drew EA, Jupp BP (1976) Light and the ecology of Laminaria hyperborea II. In: Evans GC, Bainbridge R, Rackham O (eds) Light as an Ecological Factor: II. Blackwell, Oxford, pp 63-92

Prentice SA, Kain JM (1976) Numerical analysis of subtidal communities on rocky shores. Estuar Coast Mar Sci 4:65-70

Kain JM (1977) The biology of Laminaria hyperborea X. The effect of depth on some populations. J Mar Biol Ass UK 57:587-607

Hopkin RD, Kain JM (1978) The effects of some pollutants on the survival, growth and respiration of Laminaria hyperborea. Estuar Coast Mar Sci 7:531-553

Kain JM (1979) A view of the genus Laminaria. Oceanogr Mar Biol Ann Rev 17:101-161

Jones JM, Holt TJ (1981) Biomass from offshore sea areas. In: Chartier P, Palz W (eds) Solar Energy R \& D in the European Community, Series E: Energy from Biomass 1. Reidel, Amsterdam, pp 85-89

Morley JG, Jones JM (1981) Growth of marine biomass on artificial structures as a renewable energy source. In: Palz W, Chartier P, Hall DO (eds) Energy from Biomass, 1st EC Conference. Applied Science Publishers, London, pp 681-685

Kain JM (1982) Morphology and growth of the giant kelp Macrocystis pyrifera in New Zealand and California. Mar Biol 67:143-157

Kain JM (1982) The reproductive phenology of nine species of Rhodophyta in the subtidal region of the Isle of Man. Br Phycol J 17:321-331

Kain JM, Holt TJ (1982) Biomass from offshore sea areas. In: Grassi G, Palz W(eds) Solar Energy R \& D. in the European Community, Series E: Energy from Biomass, Reidel, Amsterdam pp 120-125

Holt, TJ and Kain (Jones) JM (1983) The cultivation of large brown algae as an energy crop. In: Strub A, Chartier P, Schleser G (eds) Energy from Biomass. Proceedings of the International Conference on Biomass held in Berlin, Federal Republic of Germany, 20-23 September 1982. Applied Science Publishers, London, pp 319-323.

Kain JM (1984) Seasonal growth of two subtidal species of Rhodophyta off the Isle of Man. J Exp Mar Biol Ecol 82:207-220
Kain (J)JM, Holt TJ (1984) Biomass from offshore sea areas. In: Palz W, Pirrwitz D (eds) Solar Energy R \& D in the European Community, Series E: Energy from Biomass 5. Reidel, Amsterdam, pp 168-176

Jones JM, Holt TJ (1985) The cultivation of large brown algae as an energy crop. Commission of the European Communities, Directorate-General Informationa Market and Innovation, Luxembourg. EUR 9990 EN, 78 pp

Kain JM (1986) Plant size and reproductive phenology of six species of Rhodophyta in subtidal Isle of Man. Br Phycol J 21:129-138

Kain JM (1986) Seasonal growth of Plocamium cartilagineum and inhibition by high light. Br Phycol J 21: 331. (Abstract)

Kain JM, Dawes CP, Holt TJ (1986) Kelp farming off the Isle of Man. British Phycological Society Newsletter, Dec, 2-3. (Abstract)

Kain JM (1987) Seasonal growth and photoinhibition of Plocamium cartilagineum (Rhodophyta) off the Isle of Man. Phycologia 26: 88-99

Kain JM (1987) Photoperiod and temperature as triggers in the seasonality of Delesseria sanguinea. Helgol Wiss Meeresunters 41:355-370

Kain JM (1987) Patterns of relative growth in Nereocystis luetkeana (Phaeophyta). J Phycol 23:181-187

Kain JM, Dawes CP (1987) Useful European seaweeds: past hopes and present cultivation. In: Ragan MA, Bird CJ (eds) Proceedings of the Twelfth International Seaweed Symposium. Junk, Dordrecht, pp 173-181

Kain JM, Norton TA, Montegut AE (1987) Growth of blades of Nereocystis luetkeana in darkness. J Phycol 23:464-469

Kain JM, Dawes CP, Holt TJ (1988) Cultivation of kelps in the British Isles and the potential in Europe. In: de Waart J, Nienhuis PH (eds) Proc. 2nd Workshop COST 48 Subgroup 3, pp 16-19.

Kain JM (1989) The seasons in the subtidal. Br Phycol J 24:203-215

Kain JM, Holt TJ, Dawes CP (1989) Cultivating kelps off the Isle of Man. Marinetech Research 13:9-11

Sohn CH, Kain JM (1989) Undaria, Laminaria and Enteromorpha cultivation in Korea. In: Kain JM, Andrews JW, McGregor BJ (eds) Outdoor Seaweed Cultivation, Proceedings of the Second Workshop of COST 48 Subgroup 1. European Economic Community, Brussels, pp 42-45

Sohn CH, Kain JM (1989) Porphyra cultivation in Korea. In: Kain JM, Andrews JW, McGregor BJ (eds) Outdoor Seaweed Cultivation, Proceedings of the Second Workshop of COST 48. European Economic Community, Brussels, pp 106-109

Kain JM, Holt TJ, Dawes CP (1990) European Laminariales and their cultivation. In: Yarish C, Penniman CA, Van Patten P (eds) Economically Important Marine Plants of the Atlantic: Their Biology and Cultivation. Connecticut Sea Grant College Program, Groton, pp 95-111

Savidge G, Kain JM (1990) Productivity of the Irish Sea. In: Norton TA, Geffen AJ (eds) Irish Sea Study Group Report Part 3 Exploitable Living Resources. University Press, Liverpool, pp 9-43

Kain JM, Norton TA (1990) Marine ecology. In: Cole K, Sheath R (eds) Biology of the Red Algae. Cambridge University Press, Cambridge, pp 377-422

Kain JM (1991) Cultivation of attached seaweeds. In: Guiry MD, Blunden G (eds) Seaweed Resources in Europe: Uses and Potential. John Wiley \& Sons, London, pp 309-377

Kain JM (1991) Why does Delesseria sanguinea stop growing in the summer? Oebalia 17 (2 Suppl.) 485-92.

Han T, Kain JM (1992) Blue light sensitivity of UV-irradiated young sporophytes of Laminaria hyperborea. J Exp Mar Biol Ecol 158: 219-230

Hawkins SJ, Hartnoll RG, Kain JM, Norton TA (1992) Plant-animal interactions on hard substrata in the north-east Atlantic. In: John DM, Hawkins SJ, Price JH (eds) Plant-Animal Interactions in the Marine Benthos. Systematics Association Special Volume 46, Clarendon Press, Oxford pp 1-32 
Han T, Kain JM (1993) Blue light photoreactivation in ultraviolet-irradiated young sporophytes of Alaria esculenta and Laminaria saccharina (Phaeophyta). J Phycol 29:79-81

Kain JM, Bates MJ (1993) The reproductive phenology of Delesseria sanguinea and Odonthalia dentata off the Isle of Man. Eur J Phycol 28:173-182

Kain JM (1993) Growth strategies of various members of the Laminariales in relation to their habitat. Revista de Investigaciones Cientificas y Tecnologicas, Serie: Ciencias del Mar 3:99-114

Kain JM, Destombe C (1995) A review of the life history, reproduction and phenology of Gracilaria. J Appl Phycol 7:269-281

Kain JM (1996) Photoperiodism in Delesseria sanguinea (Ceramiales, Rhodophyta) 1 . The phases and sexes differ. Phycologia 35:446455

Figueiredo MAO, Kain JM, Norton TA (1996) Biotic interactions in the colonization of crustose coralline algae by epiphytes. J Exp Mar Biol Ecol 199:303-318

Figueiredo MAO, Norton TA, Kain JM (1997) Settlement and survival of epiphytes on two intertidal crustose coralline algae. J Exp Mar Biol Ecol 213:247-260

Creed JC, Norton TA, Kain JM (1997) Intraspecific competition in Fucus serratus germlings: the interaction of light, nutrients and density. $\mathrm{J}$ Exp Mar Biol Ecol 212:211-223

Creed JC, Kain JM, Norton TA (1998) An experimental evaluation of density and plant size in two large brown seaweeds. J Phycol 34:3952
Kain JM (2003) Control of blade growth rate in Delesseria sanguinea (Rhodophyta) In: Chapman ARO, Anderson RJ, Vreeland VJ, Davison IR (eds) Seventeenth International Seaweed Symposium. University Press, Oxford, pp 403-409.

Kain JM (2003) Seaweed cultivation in the West is retarded. In: Norton TA (ed) Out of the Past. The British Phycological Society, pp 163180.

Kain JM (2006) Photoperiodism in Delesseria sanguinea (Ceramiales, Rhodophyta) 2. Daylengths are shorter underwater. Phycologia 45: 624-631

Kain JM (2008) Winter favours growth and survival of Ralfsia verrucosa (Phaeophyceae) in high intertidal rockpools in southeast Australia. Phycologia 47:498-509

Kain JM, Buchanan J, Boo SM, Lee KM (2010) Colpomenia bullosa crust masquerading as Ralfsia verrucosa (Phaeophyceae) in southeast Australia. Phycologia 49:617-627

Lee KM, Boo SM, Kain JM, Sherwood AR (2013) Cryptic in JM (1986b) Seasonal growtwidespread brown alga Colpomenia sinuosa (Ectocarpales, Phaeophyceae). Bot Mar 56: 15-25.

Kain JM (2013) Colpomenia bullosa crust (Phaeophyceae) stressed less by grazing than by abiotic factors in high intertidal rockpools in southeast Australia. Bot Mar 56:441-450

Kain JM (2015) Hormosira banksii: a tough survivor in the harsh conditions of high intertidal pools in southeast Australia. Eur J Phycol 50: 408-421 